\title{
Leadership and Effective Human Resource Management in Organization
}

\author{
Ugo C. Okolie ${ }^{1} \bowtie$, Osahon G. Omole $^{2}$, Abdulfatai Yakubu $^{3}$ \\ ${ }^{1}$ Delta State University, \\ 1, Abraka, Delta State, Nigeria \\ ${ }^{2}$ Auchi polytechnic, \\ 13, Okene R., Auchi, Edo State, Nigeria, 312101 \\ ${ }^{3}$ Auchi polytechnic, \\ 13, Okene R., Auchi, Edo State, Nigeria, 312101 \\ \ugookolie3@gmail.com
}

\begin{abstract}
Outstanding leaders combine good strategic substance and effective interpersonal processes to formulate and implement strategies that produce results and sustainable competitive advantage. In today's competitive business environment, the defining success factor is essentially leadership with the potential of transforming its employees into a willing and winning team with the appropriate synergy to actualize collectively determined corporate missions and aspirations. The contemporary dynamics in the operating environment of business calls for leadership orientations which recognize that employees have emotional dividends to satisfy at workplace and should, thus, be managed in such a way that they are always able and willing to achieve enhanced performances. It is against this backdrop that this paper underscores the indispensability of leadership in the dayto-day dynamics of the organization and suggests a ramifying range of leadership styles that potentially conduce to optimal human resources management and performance. This paper utilized the methods of qualitative and syntheses of scientific literature as it relies on secondary data collected from books and journal articles, and were content analyzed in relation to the scope of the paper. Finally, the paper concludes that leadership synergizes the human resource and ensures that they continuously create value for the various stakeholders in the organization.
\end{abstract}

Keywords: Leadership, Human Resources, Management, Organization, Performance

Conflicts of interest: The authors declared no conflicts of interest.

JEL Classification: M1, M5, M120

Article history:

The article was submitted on 27.04.2021. The article was accepted on 31.05.2021.

\section{For citation:}

Okolie U.C., Omole O.G., Yakubu A. Leadership and Effective Human Resource Management in Organization. RUDN Journal of Public Administration. 2021;8(3):277-296. DOI: 10.22363/23128313-2021-8-3-277-296

(C) Okolie U.C., Omole O.G., Yakubu A., 2021

(c) This work is licensed under a Creative Commons Attribution 4.0 International License https://creativecommons.org/licenses/by/4.0/ 


\section{Introduction}

Although the context of business and the processes of doing business are changing radically, there are still more of timeless principles that make great executives and great companies, great. While fresh thinking and new approaches are required now more than ever, much of what has already been learned about successful management practices remains relevant, useful and adaptable. In the business world today, the successful executives not only adapt to changing conditions but also apply fanatically, rigorously, consistently and with discipline the fundamental management principles. These fundamentals include the four traditional functions of management: planning, organizing, leading and controlling. They remain as relevant as ever and they still provide the fundamentals that are needed in start-ups as much as in established corporations. It is settled in the literature that management as a discipline and a professional practice has a number of discernible functions including 'leading' or 'leadership'. The centrality of leadership in the management process is equally not in doubt particularly as it involves not only visualizing a preferred future for the organization (part of the planning function) but influencing the entire workforce to faithfully implement strategies that will enable the organization to actualize its mission and vision. Thus, leadership involves close day-to-day contact with people, helping to guide and inspire them toward achieving team and organizational goals and objectives.

Leadership is usually a monumental challenge for any organization or management to determine its mission and faithfully implement the strategies that should actualize it. The defining success factor is essentially leadership with the potential of transforming its workforce, no matter how large, into a willing and winning team with the appropriate synergy to actualize collectively determined corporate missions and aspirations. Leadership therefore is invariably the defining factor in the cutting-edge performance of organizations and the panacea to all problems and the more efficacious leaders are in exerting positive influence on their followers, the brighter the prospects of achieving satisfactory performance $[1 ; 2]$. However, the instruments or motivational factors for exerting the influence may differ across organizations or among leaders but they generally recognize that employees have emotional dividends to satisfy, particularly with regard to a feeling of community, significance and excitement, and subsequently providing that satisfaction. Therefore, the objective of this paper is not only to underscore the crucial importance of leadership in organizational processes but more importantly is to identify and discuss the contemporary leadership dispositions that conduce to optimum human resource management and performance.

\section{Review of Related Literature}

There is multiplicity of the definition of leadership in management literature. A common thread among these various interpretations of leadership is that it relates to exerting influence on group members to commit themselves freely to the achievement of group tasks or goals. Leadership is a dynamic process, influenced by the changing requirements of the task, the group itself and the individual members. The implication of this is that there is no 'one best way' of leading, and 
leaders need to be able to exercise a range of behaviours to maintain their role effectively [3]. As acknowledged by Hampton [4], 'what distinguishes management work from the other work that goes on within an organization is that management work focuses on maintaining the organization so that it can accomplish its tasks'. Maintaining the organization is, of course, the challenge of leadership. Likert [5] admonishes that 'every aspect of a firm's activities' depends on the competence and motivation of the human organization and impliedly counsels that consistently delivering value to the clientele is the hallmark of contemporary management and the challenge to today's corporate leadership. This, therefore, is the crux of the matter. It is leadership that catalyzes and stimulates the value-adding potential of the entire workforce and ensures the competitiveness of the organization, particularly in the circumstances of rapid technological and competitive change in the global business environments.

Leadership is a vital element in the social relationships of groups at work. What then is leadership? According to Bateman and Snell [2. P. 16], leadership is "the management function that involves the manager's efforts to stimulate high performance by employees. It includes motivating and communicating with employees, individually and in groups". Hampton [4] sees leadership as "the interpersonal process by which mangers try to influence employees to accomplish set tasks or goals... leadership takes place not in isolation but in interaction'. In a similar vein, Schermerhorn [6] defines leadership as the process of inspiring others to work hard to accomplish important tasks. He further relates leadership to management and suggests very fittingly that while planning sets the direction and objectives, organizing brings the resources together to turn plans into action while leading builds the commitments and enthusiasm needed for people to apply their talents fully to help accomplish plans. To succeed as a leader in this action context, one must be good at dealing with all aspects of communication, interpersonal relations, motivation, job design, team work and change.

In the view of Robbins and Judge [7. P. 419], leadership is "the ability to influence a group towards the achievement of a vision or set of goals". This definition implies that leadership provides direction without which the attainment of group goals and organizational objectives would be difficult if not impossible, regardless of the resources at the disposal of the organization. In today's competitive environment, a strong leadership is imperative if an organization is to be unidirectionally focused on its mission and objectives which themselves must be sensitive to the dynamics of the marketplace and the operating environment. Without an effective leadership, an organization will inevitably experience a shortfall in its results delivery capability and may in fact go under [8]. The following comments by Davis [9] capture the point being made:

"Without leadership, an organization is but a muddle of men and machines". Leadership is to persuade others to seek defined objectives enthusiastically. It is the human factor which binds a group together and motivates it towards goals. Management activities such as planning, organizing and decisionmaking are dormant cocoons until a leader triggers the power of motivation in people and guides them towards goals. Leadership transforms potentials into reality. It is the ultimate act which brings to success all the potentials that is in an organization and its people'. 
The above comments are substantiated against the backdrop that "everything rises and falls on leadership and every endeavour you can undertake that involves other people will live or die depending on leadership" [10. P. 1]. Reasoning from this dimension, Muhammed and Danjuma [11. P. 105] simply defines leadership as "the ability to guide, direct or influence people towards the achievement of a mission and objectives". Thus, leaders are strategists who seize opportunities others overlook, but they are also passionately concerned with detail - all the small, fundamental realities that can make or mar the grandest of plans. This support the assertion of Ogbonnia, 2007 cited in Agugua [12. P. 46] who posits that an effective leader is "an individual with the capacity to consistently succeed in a given condition and be viewed as meeting the expectations of an organization or society". Leaders are recognized by their capacity for caring for others, clear communication and a commitment to persist. In the context of this paper, we define leadership as the process of stimulating organizational workforce or human resource to undertake desired action according to predetermined mission and objectives.

For further understanding of the concept of leadership, it is pertinent also to look at the qualities of a good leader. Adair [13] enumerated these qualities to have included: integrity, knowledge, courage, faith, decisiveness, dependability, tact, loyalty, sense of duty, energy, sympathy and resolution. This support the assertion of Akintayo [14] who posits that leadership qualities include honesty, ability to delegate, communication, sense of humour, confidence, commitment, positive attitude, creativity, ability to inspire and intuition. While Maxwell [15] reinforces that a good leader must have good character, charisma, committed, communicate with followers, competence, courage, discernment, focus, generosity, good initiatives, listen to followers, have passion, possess positive attitude, can solve problems, have good relationship with followers, take responsibility, have selfdiscipline, must be a servant, have teaching ability and have vision.

\section{Difference in Perspectives}

Leadership is just one important component of a manager's skills, a manger cannot just be a leader, he or she also needs formal authority to be effective. Good leadership, unfortunately, is all too rare. Mangers may focus on the activities that earn them praise and rewards, such as actions that cause a rise in the company's stock price rather than making tough ethical choice or investing in long-term results. Some new managers, learning that 'quick wins' will help them establish their credibility as leaders, push a pet project while neglecting the impact on the very people they were assigned to lead. This approach tends to backfire, because employees destruct this type of manager and lose any commitment they might have had to the team's long-term success. Successful leaders, in contract, enlist the team in scoring collective quick wins that result from working together toward a shared vision [16]. The points below illustrate ways in which leadership is different from managing: (i) mangers think incrementally, while leaders think radically, (ii) managers do things right, while leaders do the right things, this means that managers do things by the book and follow company policy, while leaders follow their own intuition, which may be of more benefit to the company, (iii) a leader is more 
emotional than a manger. That is, 'men are governed by their emotions rather than their intelligence'. This quotation illustrates why teams choose to follow leaders and (iv) leaders stand out by being different. They question assumptions and are suspicious of tradition. They seek out the truth and make decisions based on facts, not prejudice. They have a preference for innovation.

In a similar vein, Bateman and Snell [2] assert that whereas management must deal with the ongoing day-to-day complexities of organizations, true leadership includes effectively orchestrating important change while managing requires planning and budgeting routines, leading includes setting the direction (creating a vision) for the firm. Management requires structuring the organization, staffing it with capable people and monitoring activities; leadership goes beyond these functions by inspiring people to achieve the vision. Great leaders keep people focused on moving the organization toward its ideal future, motivating them to overcome whatever obstacles lie in the way. However, management and leadership are both vitally important. To highlight the need for more leadership is not to minimize the importance of management or mangers, but leadership involves unique processes that are distinguishable from basic management processes [17]. Moreover, just because they involve different processes does not mean that they require different or separate people. The same individual can exemplify effective managerial processes, leadership processes, both or neither.

\section{Power and Leadership}

An individual who is appointed to a managerial position has the right to command and enforce obedience by virtue of the authority of their position. It is only authority of position has the backing of formal sanctions. It follows that whoever wields personal influence and power can legitimize this only by gaining a formal position in the hierarchy with commensurate authority. Thus, central to effective leadership is power - the ability to influence other people. In organizations, this influence often means the ability to get things done or accomplish one's goals despite resistance from others. One of the earliest and still most useful approaches to understanding power, offered by French and Raven [18], suggests that leaders have five important potential sources of power in organizations. We will briefly examine these sources of power.

- Legitimate Power: The leader with legitimate power has the right or the authority to tell others what to do; employees are obligated to comply with legitimate orders. For instance, a supervisor tells an employee to remove a safety hazard, and the employee removes the hazard because he has to obey the authority of his boss. As you might guess, managers have more legitimate power over their direct reports than they do over their peers, bosses and others inside or outside their organization.

- Reward Power: The leader who has reward power influence others because he controls valued rewards; people comply with the leader's wishes to receive those rewards. For example, a manager works hard to achieve his performance goals to get a positive performance review and a big pay raise from his boss. On the other hand, everyone receives the same salary increase, a leader's reward power decreases because he is unable to give higher raises. 
- Coercive Power: The leader with coercive power has control over punishments; people comply to avoid those punishments. For example a manger implements an absenteeism policy that administers disciplinary actions to offending employees. A manger has less coercive power if, say, a union contract limits his ability to punish. In general, lower-level managers have less legitimate, coercive and reward power than do middle-level mangers.

- Referent power: The leader with referent power has personal characteristics that appeal to others; people comply because of admiration, personal liking, a desire for approval, or a desire to be like the leader. For instance, young, ambitious managers emulate the work habits and personal lifestyle of a successful, charismatic executive. An executive, who is incompetent, disliked and commands little respect has little referent power. $v$.

- Expert Power: The leader who has expert power has certain expertise or knowledge; people comply because they can learn from or can otherwise gain from that expertise. For instance, a sales manager gives his sales people some tips on how to close a deal. The sales people then alter their sales techniques because they respect the manager's expertise. However, this manager may lack expert power in other areas, such as finance; thus, his sales people may ignore his advice concerning financial matters.

Therefore, people who are in a position that gives them the right to tell others what to do, who can reward and punish, who are well liked and admired, and who have expertise on which other people can draw will be powerful members of the organization. All of these sources of power are potentially important. Although it is easy to assume that the most powerful executives are those who have high legitimate power and control major rewards and punishments, it is imperative not to underestimate the more 'personal' sources of power such as expert and referent $[19 ; 20]$.

\section{Traditional Approach to the Study of Leadership}

Bozeman [21] suggests that the study of leadership has been one of the most successful fields of management for the marriage of theory and practical application. It is therefore no surprise that three traditional theories/approaches have been propounded on leadership over time, namely: (i) the trait approaches (ii) the behavioural approach and (iii) the situational or contingency approach.

\section{The Trait Approach}

The trait approach is the oldest leadership perspective, it focuses on individual leaders and attempts to determine the personal characteristics (traits) that great leader share. What set Winston Churchill, Alexander the Great and Martin Luther King Jr., apart from the crowd? The trait approach assumes the existence of a leadership personality and assumes that leaders are born, not made [2]. This approach focuses on the search for personality, social, physical or intellectual attributes that would describe leaders and differentiate them from non-leaders. In other words, research in this area involved the search for universal traits that separate effective and ineffective leaders. Unfortunately, however, the early trait theories generally assumed that leaderships are uni-dimensional and therefore, had nothing to do with the overall context of work in which leadership is provided. The generally acknowledged trait theorist is E. Chiselli whose 1971 work: 'Explorations 
in Managerial talent' painstakingly employed measures for traits that had been validated and tested for reliability [22]. Of course, central to his work were the following two fundamental assumptions:

i. A number of trait characteristics are related to leadership effectiveness in formal organizations.

ii. The demands of an organization for leadership are common to all supervisory positions but increase in importance in the higher echelons of the organization.

Chiselli [22] subsequently identified the following eight personality and five motivational traits that are consistently indicators of leadership.

\section{Personality Traits:}

1 Intelligence (generally of a verbal and symbolic nature rather than creative);

2 Initiative ;

3 Supervisory ability (ability to direct others);

4Self assurance (measured in terms of self evaluation);

5 Affinity for the working class;

6Decisiveness;

7Masculinity/Femininity;

8Maturity (conformance to age-group norms).

\section{Motivational Traits:}

1 Need for occupational achievement;

2 Need for self-actualization;

3 Need for power over others;

4Need for high financial reward;

5 Little need for job security.

However, by the mid-1970s, enthusiasm for the trait approach diminished and a more balanced view emerged; although no traits ensure leadership success, certain characteristics are potentially useful. The current perspective is that some personalities characteristics many of which a person need not be born with can strive to acquire do distinguish effective leaders from other people [23; 24]. There personality characteristics include;

a) Drive (high need for achievement, constant striving for improvement, ambition, energy, tenacity and initiative);

b) Leadership motivation;

c) Integrity;

d) Self-confidence;

e) Knowledge of the business.

\section{The Behavioural Approach}

The behavioural approach to leadership attempts to identify what good leaders do. Should leaders focus on getting the job done or on keeping their followers happy? Should they make decisions autocratically or democratically? In the behavioural approach, personal characteristics are considered less important than the actual behaviours that leaders exhibit [2]. Three general categories of leadership behaviour have received particular attention: behaviours related to task performance, group maintenance and employee participation in decision-making [25]. 
a) Task Performance: Task performance behaviours are the leader's efforts to ensure that the work unit or organization reaches its goals. This dimension is variously referred to as concern for production, directive leadership, initiating structures, or closeness of supervision. It includes a focus on work speed, quality and accuracy, quantity of output, and following the rules [26]. This type of leader behaviour improves leader's job performance and organizational performance [25].

b) Group Maintenance: In exhibiting group maintenance behaviours, leaders take action to ensure the satisfaction of group members, develop and maintain harmonious work relationships, and preserve the social stability of the group. This dimension is sometimes referred to as concern for people, supportive leadership or consideration [2]. It includes a focus on people's feelings and comfort, appreciation of them and stress reduction. This type of leader behaviour has a strong positive impact on follower satisfaction, motivation and leader effectiveness.

c) Participation in Decision-Making: The outcome of the Hawthorne studies which emphasized socio-behavioural capacities of employees as determining group productivity, led to studies of possible linkage between leader's behavioural styles and group effectiveness, and the identification of three main leader behavioural styles which included, autocratic, democratic and Laissez-Faire styles. Autocratic leader makes decisions and then announces them to the group. Democratic leader solicits input from others. Democratic leadership seeks information, opinions and preferences, sometimes to the point of meeting with the group, leading discussions and using consensus or majority vote to make the final choice [27]. Laissez-Faire leader isolate himself from his superior and subordinates alike. The leader essentially made no decision nor perform his normal leadership functions unless when specifically required to do so. He does not have the initiative to praise or punish group members as the occasion warrants which often led to more negative attitudes and lower performance.

The summary outcome of the studies is the understanding that the behaviour and performance of group members differ substantially under different leadership styles. In this sense, it is observed that democratic style enhances greater group cohesion and productivity than the laissez-faire approach. In the same vein, the Autocratic leadership style results in greater productivity than the democratic style but produces less quality output than the democratic style. Also, discontentment among members is noted to be highest under the Autocratic style of leadership. The further implication of the foregoing observations are that in the absence of the leader, productivity drops significantly under the Autocratic style, and is seen to drop, slightly under a democratic leadership. In addition, democratic leadership is noted to records the least rate of absenteeism, job termination and dropouts; it also records the least level of hostility, aggressiveness, scape-goatism and apathy, all of which were seen to be at their highest levels under the autocratic style of leadership. However, submissiveness and a sense of dependency were noted to be experienced more in autocratic leadership than in either the democratic or Laissez-faire styles of leadership [28].

The most comprehensive and replicated of the behavioural theories was from Ohio State studies in the late 1940s [29]. Also, a research programme at the University of Michigan was conducted on the impact of the leader behaviours on groups' job performance. Among other things, the researchers concluded that the 
most effective managers engaged in what they called task-oriented behaviour: planning, scheduling, coordinating providing resources and setting performance goals. Effective managers also exhibited more relationship-oriented behaviour: demonstrating trust and confidence, being friendly and considerate, showing appreciation and keeping people informed. These dimensions of leader behaviour are essentially the task performance and group maintenance dimensions. The bestknown leadership training model to follow these styles is Blake and Mouton's [30] leadership Grid. In grid training, managers are rated on their performance-oriented behaviour (called concern for production) and maintenance-oriented behaviour (called concern for people). Then their scores are plotted on the grid shown in the managerial grid below. The highest score is a 9 on both dimensions. The grid has nine possible positions along each axis and, therefore, creates eighty-one (81) different positions into which a leader's style may fall.

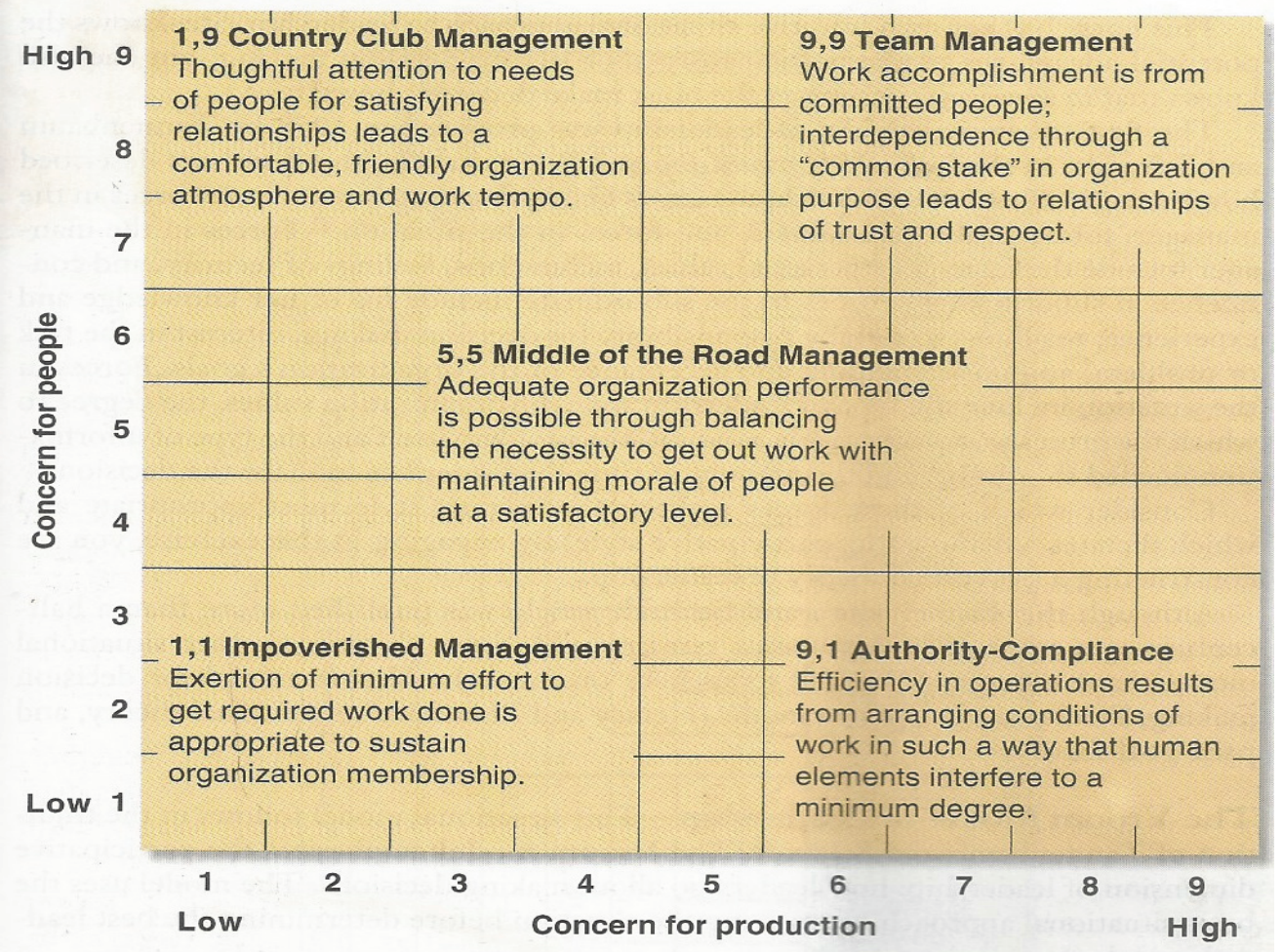

Fig. 1. Comparison of management in the prism of concern Source: [30]

There is no doubt that the leadership or managerial grid offers a good framework for conceptualizing leadership styles but it offers little substantive evidence to support the conclusion that a 9.9 style is most effective in all situations.

(iii) The Situational Approach

According to proponents of the situational approach to leadership, universally important traits and behaviours do not exist, and that effective leadership behaviour varies from situation to situation. The first situational model of leadership was proposed by Tannenbaum and Schmidt [31]. In their classic article, these authors described how managers should consider three factors before deciding how to lead; 
forces in the manager, forces in the subordinate and forces in the situation. Forces in the manager include the manager's personal values, inclinations, feelings of security and confidence in subordinates. Forces in the subordinate include his knowledge and experience, readiness to assume responsibility for decision-making, interest in the task or problem, and understanding and acceptances of the organization's goals. Forces in the situation include the types of leadership style the organization values, the degree to which the group works effectively as a unit, the problem itself and the type of information needed to solve it, and the amount of time the leader has to make the decision.

Fred E. Fiedler [32] developed the first comprehensive contingency model for leadership effectiveness. His argument was that different work environments require different leadership behaviours. In other words, Fiedler's reasoning is that no one kind of leader or style of leadership is generally the 'best' and that a leadership style is contingent on the circumstances the leader finds himself. According to Fiedler's contingency model of leadership effectiveness, effectiveness depends on two factors: the personal style of the leader and the degree to which the situation gives the leader power, control and influence over the situation [32]. That is, the favourableness of the situations or environment is determined essentially by (a) the relations between the leader and the group members, (b) the task structure, and (c) the extent to which the leader posses formal organization power.

However, the most comprehensive and generally useful situational model of leadership effectiveness is path-goals theory developed by Robert J. House [33]. Path-goal theory is a theory that concerns how leaders influence subordinates' perceptions of their work goals and the paths they follow toward attainment of those goals [2]. The key situational factors in path-goal theory are (a) personal characteristics of followers and (b) environmental pressures and demands with which followers must cope to attain their work goals. These factors determine which leadership behaviours are most appropriate. The four pertinent leadership behaviours are as follows:

i) Directive Leadership: A form of task performance oriented behavior.

ii) Supportive Leadership: A form of group maintenance oriented behaviour.

iii) Participative Leadership: To what extent should leaders involve their followers in making decisions?

iv) Achievement-Oriented Leadership: A form of behaviour geared toward motivating people, such as setting challenging goals and rewarding good performance [33].

According to the path-goal theory, personal characteristics of followers and environmental factors determine the appropriateness of various leadership styles as shown in the path-goal framework below.

\section{Contemporary Perspectives on Leadership}

So far, we have addressed the major classical approaches to understanding leadership, all of which remain useful today. Now we will discuss a number of new developments that are revolutionizing our understanding of leadership. Bass [34] and Yammarino, Dansereau and Kennedy [35] developed the idea of three different types of leadership: (i) Transformational (ii) Transactional and (iii) Charismatic leadership. 


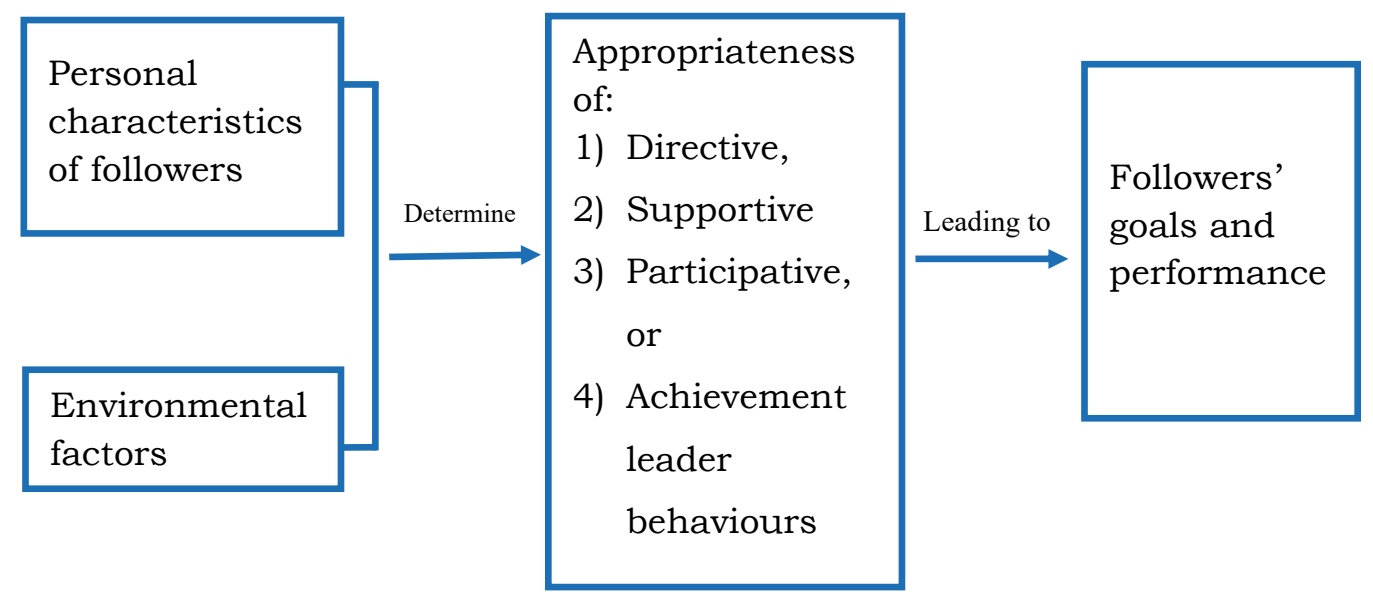

Fig. 2 Path-Goal Framework Source: [2]

\section{i. Transformational Leadership.}

Sometimes people do things for others without expecting any kind of reward, for instance, mother's dedicated service to her child. A mother does not expect anything from the child and the service she provides in raising the child is unconditional, dedicated or committed. The mother plays a role in shaping the child life. This type of relation is described as 'transformational'. Transformational leaders are often self-sacrificing, work toward a common goal with followers; put followers in front and develop them. They inspire followers to transcend their own self-interests in achieving superior results [14]. This supports the assertion of Howell and Hall-Merenda [36] who posited that transformational leaders get people to transcend their personal interests for the sake of the larger community. They generate excitement and revitalize organizations [35].

\section{ii. Transactional Leadership}

Transactional leaders view management as a series of transactions in which they use their legitimate, reward and coercive powers to give commands and exchange rewards for services rendered [34]. Unlike transformational leadership, transactional leadership is dispassionate; it does not excite, transform, empower or inspire people to focus on the interests of the group or organization. In business, leaders announce rewards in turn to encourage, productivity. These relations are all about requirements, conditions and rewards (or punishment).

\section{iii. Charismatic Leadership}

Charismatic leaders are dominant, exceptionally self-confident, and have a strong conviction in the moral righteousness of their beliefs [37]. They strive to create an aura of competence and success and communicate high expectations for and confidence in followers [2]. Ultimately, charismatic leaders satisfy other peoples' needs [38]. The charismatic leader articulates ideological goals and makes sacrifices in pursuit of those goals. The charismatic leader also arouses a sense of excitement and adventure. He is an eloquent speaker who exhibits superior verbal skills which helps communicate the vision and motivate followers. Walt Disney Mesmerized people with his storytelling; had enormous talent and instilled in his 
organization strong values of good taste, risk taking and innovation [39; 2]. Leaders who posses these characteristics inspire in their followers trust, confidence, acceptance, obedience, emotional involvement, affection, admiration and higher performance [40]. Martin Luther King Jr., John F. Kennedy, Thomas Watson, Goodluck Ebere Jonathan, Barack Obama, Nelson Mandela, Richard Branson, Steve Jobs, Umaru Musa Yar'adua, Alfred Sloan and Ronald Reagan are good examples of charismatic leaders.

\section{Qualities of an Effective Team Leader}

An effective team leader is very essential for organizational performance. Such leader expected to have these qualities:

1. Technical competence: A leader must possess technical competence to a level that would enable subordinates respect and recognize the standard of work required by his team

2. Work context: A leader should endeavour to acquire a thorough understanding of the context in which the work of the team is being carried out. This involves knowledge of the environment as well as the circumstances surrounding the tasks at hand

3. Acquaintance with team members: He needs to understand and show concern for the needs and sensitivities of team members

4. Team spirit: A leader needs to build team spirit and maintain internal cohesion of the team

5. Inspiration: A leader must continually seek ways to inspire the team members

6. Leadership by example: A leader need to lead by example and not by precepts

7. Authority: A team leader has to rely less on coercive power inherent in office as a manager and focus more on achieving compliance which comes from the respect and acceptance that team members have come to have for leaders

8. Trust and confidence: The team leader must engender, trust and confidence not only in his abilities, but in sense of fairness and justice. He must have deep conviction and commitment of what he does. In addition, he should have a strong belief in the vision of the team and unshakeable confidence and trust that the team will realizes its vision.

9. Sound judgment: A leader must have the ability to appraise situation thoroughly and not be afraid to confront facts that are uncomfortable

10. Support and communication: A leader must communicate at times of great impatience and sense of urgency. He must be approachable; open to new idea and supportive of his team even in times of difficulty [12].

\section{Theoretical Framework}

In our attempt to place this paper in its proper perspective, the need for a theoretical framework of analysis is very fundamental. While there are several theories which might prove appropriate for a discourse of this nature, the LeaderMember Exchange (LMX) theory present us with a heuristic tool for interrogating the central issues of this paper. The Leader-Member Exchange (LMX) theory, as 
developed by Graen and Uhi-Bien [41] highlights the importance of leader behaviours not just toward the group as a whole but toward individuals on a personal basis. The focus in the original formulations, which has sicne been expanded, is primarily on the leader behaviours historically considered group maintenance. According to LMX theory, and as supported by research evidence, maintenance behaviours such as trust, open communication, mutual respect, mutual obligation and mutual loyalty form the cornerstone of relationships that are satisfying and perhaps more productive [42]. LMX theory emphasizes that leadership is an exchange process between the leader and followers. In other words, subordinates affect their leaders' behaviour just as leaders' behaviour affects subordinates. For example, group productivity has a greater impact on leadership style than leadership style has on group productivity.

The relevance of this theory to this research paper is based on its ability to justify the imperative of a leadership disposition that not only envisions a desired future for the organization but continuously exerts influence on the human factor of production whether singly, in group or the entire organization as a social machine and network of relations to conduce superior performance.

\section{Human Resource Management: An Overview}

Human resource management is the process of managing human talent to achieve an organization's objectives. We use a lot of words to describe the importance of people to organizations. The term 'human resource' implies that people have capabilities that drive organizational performance (along with other resources such as money, materials and information). Other terms such as human capital and intellectual assets all have in common the idea that people make the difference in how an organization performs [2]. What human resource management (HRM) advocates is that decisions about the employment and management of the "people" resource should not have an independent life of their own but should be firmly rooted in the mission and strategy of the organization. It is therefore logical that the agenda that HRM covers and the focus it brings to bear on "people issues" include:

Performance: An emphasis on processes and systems that promote measure and manage the performance of the workforce.

Development: HRM espouses the need not just to maximize short-term performance but also to develop the long-run potential of the workforce - investing in human as well as physical capital and, in particular, seeking to develop the capacity and skills of managers.

Culture: A distinguishing feature of HRM is that is sees the culture of the organization as something that can be shaped, adapted and managed. This is of crucial importance because, in making the shift away from military-style command and control method of management, organizations have a great need to use culture and values to reinforce behaviour and thus achieve the required control over performance.

Integration: One of the hallmarks of HRM is that it seeks to bring together the otherwise disparate aspects of employment policy into a consistent whole that supports the organization's business strategy and which maximizes the sense of commitment that the individual employees feels towards the organization. 
To the extent that most organizations now take a long-term view of their mandate, formulate mission statements and make strategic choices, they possess the basic infrastructure for the niceties of human resource management.

\section{Leadership for Effective Human Resource Management}

The above distinctive characteristics and challenges of HRM underscore the imperative of a leadership disposition that not only energizes and invigorates the entire workforce but conduces to superior performance. To be effective in the management of human resources implies, in the main, that the affairs of the entire workforce should be managed in such a way that all employees are psychologically reconciled to the tendencies at work and are always able and willing to attain competitive, if not superior, performance. While 'ability' here has to do with the complement of skills, knowledge and competence that the workforce possesses and 'willingness' implies that the content of the work and the circumstances in which job tasks are discharged should not only be intrinsically (and psychologically) satisfactory but physiologically rewarding. The ramifying range of HRM practices including human resource planning, training and development, employee relations, employee appraisal and compensation, welfare services, etc., should not solely be the prerogative of HR professionals but should be an inclusive, organization-wide affair. In other words, the leadership disposition in the various hierarchies should be such that across the organization, there should profound feeling of participation, involvement, inclusiveness and ownership among members of staff.

Leadership styles, orientations and practices across the organization should be so enabling that the generality of the workforce readily cultivates a mentality of 'esprit de corps' and ownership about their work and use their collective synergy to ride the crest of competition and achieve superior performance. But how leadership orientation and practices would assist in effectively managing the human resource for satisfying, competitive and superior performance? The rest of this section focuses on answering this question. We should, perhaps, start by highlighting some leadership practices that potentially detract from the effective management of human resources. These negative leadership practices include:

(1) A dictatorial and autocratic leadership orientation that largely enslaved to extant rules and regulations irrespective of the impediments they pose for results delivery. This leadership tendency that is particularly prevalent in the public sector.

(2) A limited participative leadership orientation which largely alienates the majority of the workforce.

(3) A winner-take-all leadership mentality which makes top-most echelons of the organization (private or public) to corner all the material gains from work.

(4) A leadership orientation that has a token or peripheral interest in the career progress and general material welfare of subordinate officers/managers.

(5) A largely laissez-faire leadership orientation that unwillingly courts systemic de-motivation and under-achievement.

(6) A near-absence of a strategizing ethos and culture and the consequent recourse to uncoordinated day-to-date operational management that hardly benefits from the guiding light of a corporate mission and its complement of strategies.

(7) The absence of variants of the transformational leadership style which are supposed to galvanize the competence of the entire organization and use them as leverage for optimizing the potential and competitiveness of the organization. 
(8) A leadership style that seeks for loop-holes in all company policies, regulations and decisions relating to human resource management (e.g., manpower training and development, postings, retirement benefits, etc.) for purposes of graft, corruption and other trappings of bad governance.

Without intending to cast any aspersion, it could be asserted that most of the leadership frailties identified above are more prevalent in the public sector of a developing country like Nigeria where the day-to-day operational management of issues relating to the workforce - is hardly essence-driven. In contrast, human resource management in Nigeria's private sector appears largely to be guided by the imperatives of corporate missions and strategies. Leadership in the sector seems, therefore, to be uni-directionally focused on creating wealth for its stakeholders as well as striving towards turning their organizations into industry leaders. An increasingly diversifying ownership structure in Nigeria, coupled with the increasing growth and sophistication of the capital market, continuously encourage intra-industry rivalry not only for investment funds but also for credible performance returns on those investments. Expectedly, human resource management practices in the sector appear to be relatively enabling to managers as well as the generality of workers. The situation, however, could be better. The challenge of the rest of this paper is to identify and discuss the leadership orientations that conduce to effective and productive human resource management in both sectors of any economy. This is the era of 'super leaders' who, through vision and strength of personality, have a truly inspirational impact on others [43]. Their leadership efforts result in followers not only meeting performance expectations but performing above and beyond them. Super leadership could be categorized into three, namely, charismatic, transformational and transactional leadership orientations which we will individually examine after we have discussed the visionary leadership disposition. As would be expected, the following leadership orientations conduce to effective human resource management:

Visionary Leadership: A leadership with this orientation generates ideas and a clear sense of direction as well as communicating all these to the hierarchy of the organization. It develops excitement about accomplishing shared "dreams". Accordingly, a visionary leadership stimulates the human resource by:

(1) Encouraging people to challenge the process and being: pioneers through innovative effort. This leadership disposition encourages people who have ideas;

(2) Inspiring others, through its own enthusiasm, to share in a common vision;

(3) Helping others to act. It encourages team effort and supports the efforts and talents of others;

(4) Setting the example. It therefore provides a consistent role: model of how other members of staff can and should act;

(5) Celebrating achievement. This helps to bring emotion into the workplace, and raffles every 'heart' and 'mind' towards greater achievement.

Transformation 1 Leadership: This style uses the charisma and related qualities of the leader to raise aspirations and shift people and organizational systems into high-performance patterns. In other words, the leader's charisma is used to generate a high performance organizational culture. As Schermerhorn [6] aptly puts it, "the transformational leader provides a strong aura of vision and contagious enthusiasm that substantially raises the confidence, aspirations, and 
commitment of followers. The transformational leader arouses followers to be more highly dedicated, more satisfied with their work, and more willing to put extra effort to achieve success in challenging limes'. According to Gardner [43] and Kouzes and Posner, the characteristics of transformational leaders include;

(a) Vision: Having ideas and a clear sense of direction, communicating them to others, developing excitement about accomplishing shared dreams.

(b) Charisma: Arousing others' enthusiasm, faith, loyalty, pride, and trust in themselves through the power of personal reference and appeals to emotion.

(c) Symbolism: Identifying 'heroes', offering special rewards, and holding spontaneous and planned ceremonies to celebrate excellence and high achievement.

(d) Empowerment: Helping others to develop, removing performance obstacles, sharing responsibilities, and delegating challenging work.

(e) Intellectual Stimulation: Gaining the involvement of others by creating awareness of problems and stirring their imagination to create high-quality solutions.

(f) Integrity: Being honest and credible, acting consistently out of personal conviction, and by following through commitments.

Charismatic Leadership: This leadership stimulates the workforce for results by cultivating special leader-follower relationships. It inspires the followers in extra-ordinary ways. It arouses enthusiasm in the entire workforce and encourages them to have faith, loyalty, pride and trust in themselves through the power of personal reference and appeals to emotions.

Transactional Leadership: This leadership ensures that the tasks, structures and reward systems aid corporate productivity as well as assist workers to meet their needs. This leadership style therefore helps followers (employees) to satisfy their needs while working to accomplish organizational objectives.

Directive Leadership: This leadership style allows subordinates to know what are expected in the context of the vision, giving directives on what to do and how; scheduling work to done and maintaining definite standards of performance.

Supportive Leadership: This leadership orientation is characterized by doing things to make work more pleasant; treating group members or workers as equals, being friendly approachable and showing concerns for the well-being of subordinates.

Achievement-Oriented Leadership: This style enables the leader to set challenging goals and to expect improvements in performance. This leadership emphasizes continuous improvements in performance while exuding confidence in the ability of workers to meet high standards.

Participative Leadership: This leadership involves subordinates in decision making by consulting with them, asking for suggestions and cultivating an 'ideasare-welcome' atmosphere. It does not arrogate all the wisdom about work to itself and therefore widely seeks the opinion of workers on the challenges of work and productivity improvements at work.

Empowerment Leadership Style: Empowerment in management is the process of granting employees power to initiate change, thereby encouraging them to take charge of what they do. Empowerment encourages employees to become innovators and managers of their own work, and it involves them in their jobs in ways that give them more control and autonomous decision-making capabilities. 
The expectation is that effective HRM practices will empower employees generally. The idea is that when people feel empowered and powerful, they become more willing to make decisions and take the required actions to execute their tasks and achieve results for the organization. Indeed, in today's changing and competitive business environment, it is a crucial challenge to HR professionals or managers to imbue the workforce with the mentality that corporate success depends largely on how much power can be mobilized from all ranks of employees. In order to empower employees, HR professionals or managers could cultivate the entire staff complement of the organization to appreciate and practice management along the following guidelines:

1. Get subordinates involved in selecting their work assignments and the methods for accomplishing tasks.

2. Create an environment of cooperation, information sharing, discussion, and shared ownership of goals.

3. Encourage others to take initiative, make decisions, and use their knowledge.

4. When problems arise, find out what others think and let them help to design the solutions.

5. Create freedom for subordinates to put their ideas and solutions into practice.

6. Maintain high motivation and confidence by recognizing successes and encouraging high performance.

\section{Conclusion}

In this globalization era in which companies and organizations compete with the rest of the world, it is imperative for the leaders to inspire a shared vision with their workforce, which will foster collaboration. This will encourage individual contribution leading to organizational success. What human resource management requires in these contemporary times is that managers have to manage the relationship with their employees directly and in full glare of the light of their new responsibility of aligning the management of people with the business goals of their organization as a whole. The crucial role of leadership in these challenges is to create a management environment that will not only generate a profound sense of ownership of their jobs in the entire workforce but also create the necessary spark to awaken the potential of each employee to take the initiative in performing leaderlike acts. Effective leaders do not rely on one leadership style; rather, they are capable of using different styles as the situation warrants and effective human resource management seeks essentially to empower the workforce and help individuals to appreciate and pursue shared vision. The expected results that is consistently better than those of the competitors. In today's competitive business environment, leaders serve people best when they help them develop their own initiative and good judgment, enable them to grow and help them become better contributors. Human resources leaders believe in people and communicate that belief, they are accessible and visible, they support, increase participation, empower and share information. In conclusion, leadership synergizes the human resource and ensures that they continuously create value for the various stakeholders in the organization. 


\section{REFERENCES}

[1] Hall R.H. Organizations, Structures, Processes and Outcomes. Englewood's Cliffs, Near JERSEY: Prentice-Hall; 1991.

[2] Bateman T.S., Snell S.A. Management: Leading \& Collaborating in a competitive world. New York: McGraw-Hill; 2011.

[3] Cole G.A. Personnel and Human Resources Management. United State: Cengage Learning EMEA; 2002.

[4] Hampton D.R. Comtmeporary Management. New York: McGraw-Hill; 1981.

[5] Likert R. The Human Organization: its Management and Values. New York: McGraw-Hill; 1967.

[6] Schermerhorn J.R. Management. New York: John Wiley and Sons Inc; 1991.

[7] Robbins S., Judge T. Organizational Behaviour. New Jersey: Pearson education International; 2009.

[8] Lyman W.P., Bigley G.A. Motivation and Leadership at Work. New York: Mcgraw Hill; 1996.

[9] Davis K. Human Relations at Work. New York: McGraw-Hill; 1972.

[10] Bennis W. On Becoming a Leader. New York: Addison-Wesley; 1989.

[11] Mahammed N., Danjuma D. Leadership and Critical Thinking: An Exploratory Search for a Nexus. In C. Chukwumma (ed.). Leadership and Complex Military Operations. Kaduna: Nigerian Defence Academy; 2016.

[12] Agugua A. Organization Behaviour and Performance. Lagos: Chartered Institute of Personnel Management of Nigeria; 2018.

[13] Adair J. Training for Leadership. New York: MacDonald; 1968.

[14] Akintayo O.A. Gender and leadership. African Journal of Technology Policy, 2007;2(1):165-191.

[15] Maxwell J. The 21st Irrefutable Laws of Leadership: Follow Them and People will Follow You. New York: Thomas Nelson Publishers; 1998.

[16] Mark E.V.B., Todd S. Collective Quick Wins. Computer World (January 26). 2009;24-25.

[17] Yukl G.A. Leadership in Organizations. Englewood Cliffs, NJ: Prentice-Hill; 1994.

[18] French J.R.P., Raven, B. The Bases of Social Power. In D. Cartwright(ed). Studies in Social Power. Ann Arbor, MI: Institute for Social Research; 1959.

[19] Yukl G., Falbe C. Importance of Different Power Sources in Downward and Lateral Relations. Journal of Applied Psychology. 1991;76(3):416-423.

[20] Ali A. The Role of Leadership in Human Resources Management: Proposing Conceptual Framework of Advanced Leadership Model. Interdisciplinary Journal of Contemporary Research in Business. 2012;4(6):979-989.

[21] Bozeman B. Public management and Policy Analysis. New York: St Martin's Press; 1979.

[22] Chiselli E. Explorations in Management Talent. California, Santa Monica: Good Year Publications; 1971.

[23] Kirkpatrick S., Locke E. Leadership: Do Traits Matter?. Academy of Management Executive. 1991;5(2):48-60. DOI: https://doi.org/10.5465/ame.1991.4274679

[24] Foti R., Hauenstein N.M.A. Pattern and variable approaches in leadership emergence and effectiveness. Journal of Applied Psychology. 2007;92(2):347-355. DOI: 10.1037/00219010.92.2.347

[25] Judge T., Piccolo R., Ilies R. The Forgotten Ones? The Validity of Consideration and Initiating Structure in Leadership Research. Journal of Applied Psychology. 2004;89(1):36-51.

[26] Misumi J., Peterson M. The Performance-Maintenance (PM) Theory of Leadership: Review of a Japanese Research Program. Administrative Science Quarterly. 1985;30(2):198-223.

[27] Wagner J. Participation's Effect on Performance and Satisfaction: A Reconsideration of Research. Academy of Management Research. 1994;19(2):312-330.

[28] Asika N. Leadership in Organization. In A. Ejiogu \& N. Asika (eds). Readings in Organizational Behavior in Nigeria. Lagos: Malthouse Press; 1995.

[29] Stogdill R.M., Coons A.E. Leader Behaviour: its Description and Measurement. Columbus: Ohio State University Press; 1951.

[30] Blake R.R., Mouton J.S. The Managerial Grid. Houston: Gulf Publishers; 1964.

[31] Tannenebaum A. Schmidt W. How to Choose a Leadership Pattern. Harvard: Business Review. 1958;36(1):95-101. 
[32] Fiedler F.E. A Theory of Leadership Effectiveness. New York: McGraw-Hill; 1967.

[33] House R.J. A Path-goal Theory of Leadership Effectiveness. Administrative Science Quarterly. 1971;16(3):321-338.

[34] Bass B.M. Stogdill's Handbook of Leadership. New York: Free Press; 1981.

[35] Yammarino F.J., Dansereau F., Kennedy C.J. A Multiple-level Multidimensional Approach to Leadership: Viewing Leadership Through an Elephant's Eye. Organizational Dynamics. 2001;29(3):149-163.

[36] Howell J.M., Hall-Merenda K.E. The Ties that Bind: The Impact of Leader-Member Exchange, Transformational and Transactional Leadership and Distance on Predicting Follower Performance. Journal of Applied psychology. 1999;84(5):680-694. DOI: 10.1037/ 0021-9010.84.5.680

[37] Potts M., Behr B. The Leading Edge. New York: McGraw-Hill; 1987.

[38] Howell J., Shamir B. The Role of Followers in the Charismatic Leadership Process: Relationships and Their Consequences. Academy of Management Research. 2005;30(1):96-112.

[39] Howell J.M., Behr B. Leadership Effectiveness. New York: McGraw-Hill; 2006.

[40] Waldman D.A., Yammarino F.J. CEO Charismatic Leadership: Levels of Management and Levels of Analysis Effects. Academy of Management Research. 1999;24(2):266-285.

[41] Graen G., Uhi-Bien M. Relationship-based Approach to Leadership: Development of Leader-Member Exchange (LMX) Theory of Leadership over 25 Years: Applying a Multilevel Multi-domain Perspective. Leadership Quarterly. 1995;6(2):219-247.

[42] Gerstner C.R., Day D.V. Meta-analytic Review of Leader-Member Exchange Theory: Correlates and Construct Issues. Journal of Applied Psychology. 1997;82(6):827-844.

[43] Gardner J.W. The Concept and Attributes of Leadership. New management. 1988;5(1):18-22.

\title{
Information about the authors:
}

Ugo C. Okolie - PhD, Lecturer of the Department of Political Science, Delta State University, (e-mail: ugookolie3@gmail.com).

Osahon G. Omole - Confidential Secretary at Auchi polytechnic (Nigeria) (e-mail: omoleglo@gmail.com). Abdulfatai Yakubu - Researcher of the Department of Student Industrial Work Experience Auchi polytechnic, Edo State, Nigeria (e-mail: yakubuab@gmail.com).

\section{Лидерство и эффективное управление человеческими ресурсами в организации}

\author{
У.Ч. Околи ${ }^{1} \bowtie$, О.Г. Омоле 2 А. Якубу ${ }^{3}$ \\ ${ }^{1}$ Государственный университет Дельты, \\ 1, Абрака, штат Дельта, Нигерия \\ ${ }^{2}$ Политехнический институт Аучи, \\ 13, Окене д., Аучи, штат Эдо, Нигерия, 312101 \\ ${ }^{3}$ Политехнический институт Аучи, \\ 13, Окене д., Аучи, штат Эдо, Нигерия, 312101 \\ \ugookolie3@gmail.com
}

\begin{abstract}
Аннотация. Выдающиеся лидеры сочетают успешную стратегию, ее формирование и реализацию, с эффективными навыки межличностных отношений, что приводит к устойчивым конкурентным преимуществам. В сегодняшней конкурентной деловой среде определяющим фактором успеха, по сути, является лидерство как способность превратить своих сотрудников в готовую к работе и успешную команду с соответствующей синергетикой для реализации коллективно ориентированных корпоративных миссий и устремлений. Современная динамика условий функционирования организации требует от руководства признания того, что сотрудникам необходимо эмоциональное подкрепление, которое необходимо
\end{abstract}


создавать на рабочем месте и управлять таким образом, чтобы они всегда были в состоянии и желали добиваться более высоких результатов. Именно на этом фоне в данной статье подчеркивается незаменимость лидерства в повседневной динамике организации и предлагается разветвленный диапазон стилей лидерства, которые потенциально способствуют оптимальному управлению человеческими ресурсами и повышению производительности труда. В этой статье используются методы качественного анализа и синтеза научной литературы, поскольку исследование опирается на вторичные данные, собранные из книг и научных статей, к которым также был применен контент анализ для определения предметного поля. Наконец, в статье делается вывод о том, что лидерство призвано создавать эффект синергии человеческих ресурсов, что гарантирует непрерывное создание ценностей для различных заинтересованных сторон в организации.

Ключевые слова: лидерство, человеческие ресурсы, менеджмент, организация, производительность

Заявление о конфликте интересов: Авторы заявляют об отсутствии конфликта интересов.

Классификация JEL: M1, M5, M120

\section{История статьи:}

Поступила в редакцию: 27.04.2021 г. Принята к публикации: 14.05.2021 г.

\section{Для цитирования:}

Околи У.Ч., Омоле О.Г., Якубу А. Лидерство и эффективное управление человеческими ресурсами в организации // Вестник Российского университета дружбы народов. Серия: Государственное и муниципальное управление. 2021. T. 8. № 3. C. 277-296. DOI: 10.22363/23128313-2021-8-3-277-296

\section{Информация об авторах:}

Уго Чукс Околи - $\mathrm{PhD}$, Преподаватель кафедры политологии Государственного университета Дельты (Нигерия) (e-mail: ugookolie3@gmail.com).

Осахон Годфри Омоле - Секретарь политехнического института Аучи (Нигерия) (е-mail: omoleglo@gmail.com).

Абдулфатай Якубу - Научный сотрудник отдела производственной практики студентов Политехнического института Аучи (Нигерия) (e-mail: yakubuab@gmail.com). 